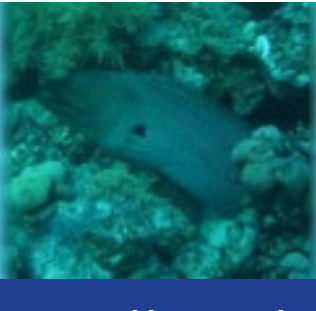

AQUATIC RESEARCH

E-ISSN 2618-6365

\title{
FIRST RECORD OF BLUE MACKEREL, Scomber australasicus (PISCES: Scombridae) IN THE BAY OF BENGAL, BANGLADESH
}

\section{Abu Hanif \\ Cite this article as: \\ Hanif, M.A. (2019). First record of blue mackerel, Scomber australasicus (Pisces: Scombridae) in the Bay of Bengal, Bangladesh. Aquatic Research, 2(4), 211-215. https://doi.org/10.3153/AR19020}

Patuakhali Science and Technology University, Department of Fisheries Biology and Genetics, Patuakhali-8602, Bangladesh

ORCID IDs of the author(s):

M.A.H. 00000-0002-9198-3879

Submitted: 01.08 .2019

Revision requested: 27.08 .2019

Last revision received: 28.08 .2019

Accepted: 29.08.2019

Published online: 04.10.2019

Correspondence:

M. Abu HANIF

E-mail: mahanif.pstu@gmail.com

\begin{abstract}
A blue mackerel, Scomber australasicus, was recorded during monthly survey on the availability of coastal and marine fish in Bangladesh. The specimen was captured from the Bay of Bengal by operating commercial gill net. This historic occurrence represents the first record of blue mackerel in the Bay of Bengal. The species was previously reported from the nearest Vizhinjam Coast of Laccadive Sea in India. The report of S. australasicus in the area further enriches the ichthyofauna of the area and points to the need for further detailed studies for conservation initiatives with respect to such rare fishes.
\end{abstract}

Keywords: First record, Scomber australasicus, Carnivorous, Bay of Bengal

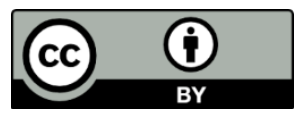

CCopyright 2019 by ScientificWebJournals

Available online at

http://aquatres.scientificwebjournals.com 


\section{Introduction}

The blue mackerel (S. australasicus, Cuvier, 1832), also known as Pacific mackerel or spotted chub mackerel is a pelagic fish species of the family scombridae. It's an oceanic species but also found in coastal water (Collette, 1995) and commonly occur within the depth of 87-200 m (May and Maxwell, 1986). This species is widely distributed in tropical and subtropical water (Tzeng et al. 2009) of Western pacific from China, Japan to Australia and New Zealand, extending east to the Hawaii and Socorro Island and Indo-West Pacific region covering Red sea, Gulf of Aden, Gulf of Oman and Persian gulf. In feeding habit, blue mackerel is carnivorous and juvenile feed on plankton while adult prefer smaller pelagic fish, krill, anchovies, squids. Blue mackerel can survive up to 7 years but mostly found within 1-3 age group (Stewart et al. 2001). Blue mackerel are consumed by humans in the form of smoke (Frimodt, 1995), grill or broil as well as used as bait for tuna and other fish.

The Bay of Bengal and its adjacent is often considered as fish biodiversity hotspot (Quader, 2010, Hanif et al. 2015, Siddik et al. 2017, Hanif et al. 2018, Hanif et al 2019). This iconic and productive ecosystem is acting as a perfect ecological niche for diversified fish species that influence non-indigenous species occurrence and establishment in this region. However, ichthyofaunal diversity of Bay of Bengal is largely unexplored till now (Hanif et al. 2019). Within the described 20 mackerel species, only one species in the genus Rastrelliger and three species in the genus Scomberomorus is reported from the territorial waters of Bangladesh. However, no species of the genus Scomber had yet been reported till now from the Bay of Bengal. Thus, the goal of this study is to report the first occurrence of $S$. australasicus in the Bay of Bengal, Bangladesh.

\section{Material and Methods}

On 17 June 2018, a single specimen of blue mackerel was collected from a fisherman after fishing by operating gill net (bar length of mesh $65 \mathrm{~mm}$ ) in the Bay of Bengal (Latitude, $21^{\circ} 40^{\prime} 53.9^{\prime \prime} \mathrm{N}$; Longitude, 89³8'09.9"E) near Dublar Char during day time at a depth approximately $38 \mathrm{~m}$ (Figure 1). Collected specimen were preserved in ice box and taken to the laboratory for identification. The specimen was identified as $S$. australasicus (Figure 2) based on morphometric and meristic characters. A digital vernier caliper was used for morphometric measurement with an accuracy of $0.01 \mathrm{~mm}$. All morphometric measurements and meristic counts are presented in Table 1. The specimen was deposited in the fisheries laboratory, Patuakhali Science and Technology University with the accession number FBG-PSTU-08.
Table 1. Biometric and meristic measurements of the specimen of $S$. australasicus collected from the Bay of Bengal, Bangladesh, 17 June 2018.

\begin{tabular}{lc}
\hline Morphometric measurements & Length (cm) \\
\hline Total length & 31.2 \\
Fork length & 29.4 \\
Standard length & 26.9 \\
Body depth & 6.3 \\
Depth of caudal peduncle & 1.6 \\
Pre-dorsal length (1st) & 10.3 \\
Pre-dorsal length (2nd) & 19.8 \\
Pre-ventral length & 9.9 \\
Pre-anal length & 19.7 \\
Dorsal fin base length (1st) & 3.9 \\
Dorsal fin base length (2nd) & 2.6 \\
Anal fin base length & 2.9 \\
Head length & 8.6 \\
Eye diameter & 1.9 \\
Pre-orbital length & 2.7 \\
Post-orbital length & 4.0 \\
\hline Meristic counts & \\
\hline Dorsal spines & 12 \\
Dorsal fin soft ray & 12 \\
Pectoral fin soft ray & 20 \\
Ventral fin soft ray & 8 \\
Anal fin soft ray & 12 \\
Branchiostegal ray & 7 \\
\hline
\end{tabular}

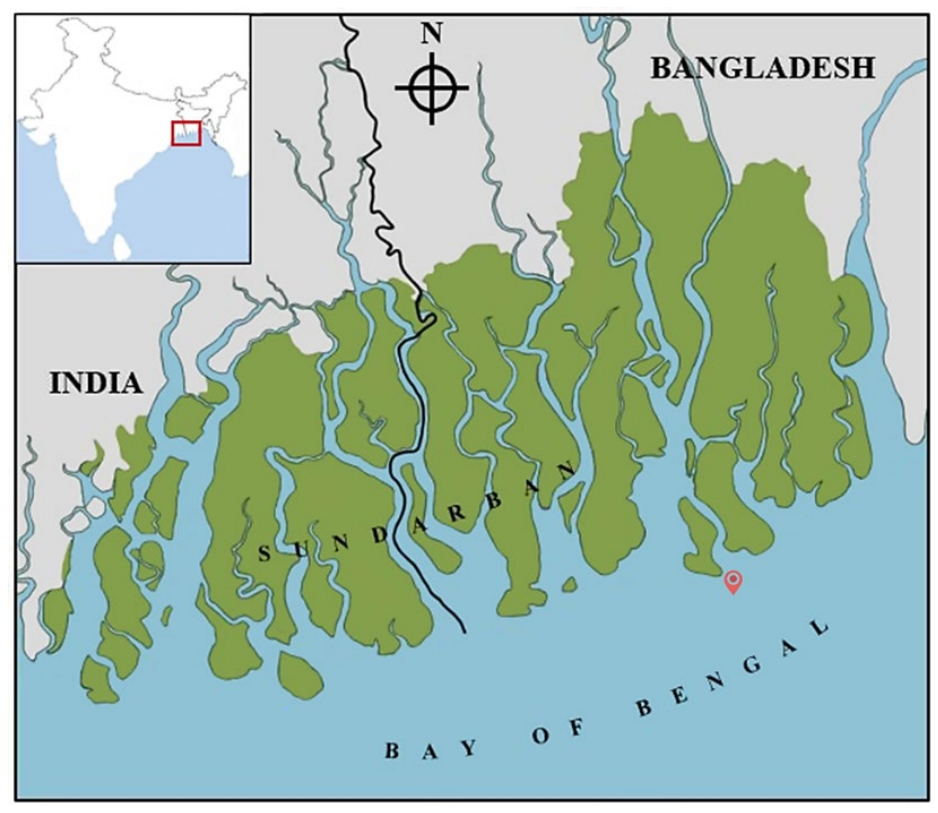

Figure 1.Sampling location of Scomber australasicus in the Bay of Bengal coast, Bangladesh on June 17, 2018. 


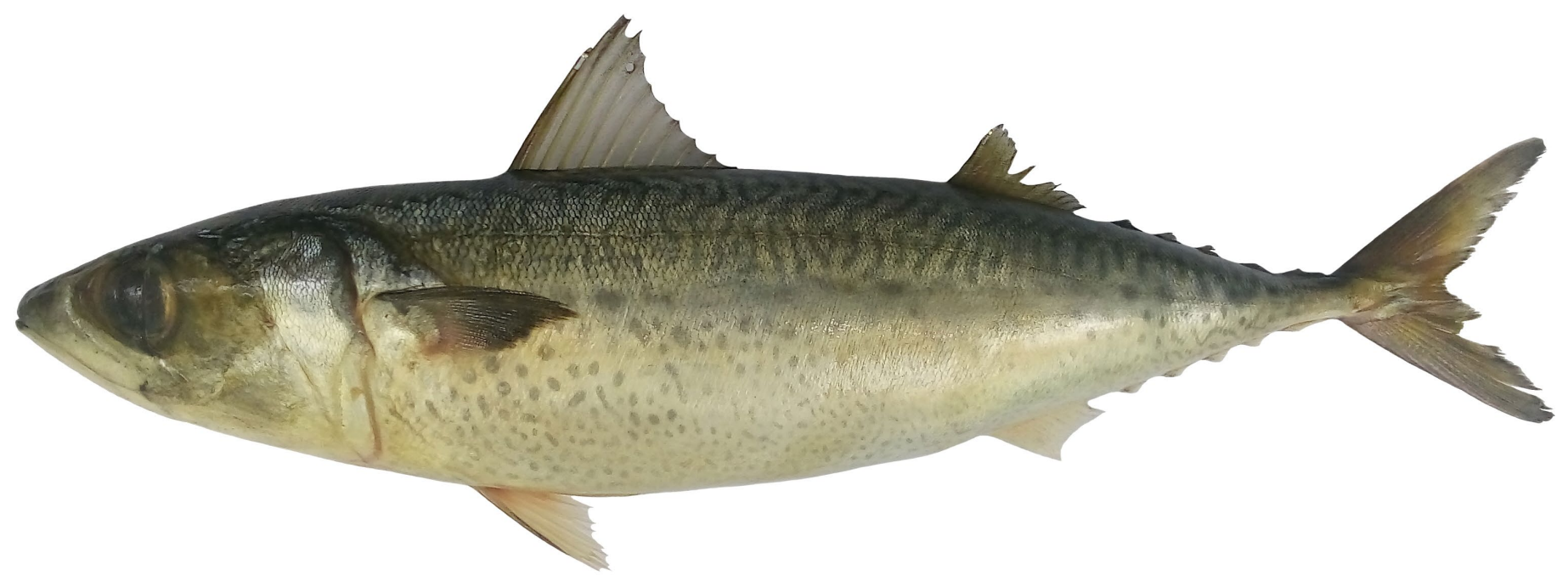

Figure 2. S. australasicus (total length $31.2 \mathrm{~cm}$ ) caught from the Bay of Bengal coast, Bangladesh.

\section{Results and Discussion}

The $S$. australasicus captured near Char Kukrimukri had a total length of $312 \mathrm{~mm}$ and a total weight of $292.28 \mathrm{~g}$. Meristic and morphometric measurements are reported in Table 1. Morphological feature, colour and both morphometric and meristic traits in accordance with previous descriptions of $S$. australasicus (Collette \& Nauen, 1983). Body elongate and rounded, snout pointed, first and second dorsal fin separated with a gap $4.2 \mathrm{~cm}$. The space between the first and second dorsal fin is less than the first dorsal fin base for S. japonicus, as long as first dorsal fin base for $S$. colias and greater (approximately 1.5 times) than first dorsal fin base for $S$. scombrus (Gopakumar et al. 1993). Behind the second dorsal and anal fin 5 finlets lies up to caudal peduncle region each. Body is covered with ctenoid scale which is more conspicuous and large aback head and around pectoral fin than oddment of the body. Dorsal part of the body dark blue to bluish in fresh condition with oblique wavy lines. Ventral side white or yellowish and marked with numerous greyish rounded blotch. Pectoral fin, second dorsal fin, caudal fin and around eyes were yellowish to grey-yellowish. Origin of anal fin is just opposite to second dorsal fin for $S$. japonicas, $S$. scombrus and $S$. colias but in case of $S$. australasicus, anal fin origin below the $4^{\text {th }}$ ray of second dorsal fin. The species has close resemblance with its congener $S$. japonicas, $S$. scombrus and S. colias.

In the Bay of Bengal, the presence of $S$. australasicus is not surprising as this species widely distributed in both tropical and subtropical region. This tropical marine ecosystem has copious river drainage into the northern part of the bay and profusion of wetlands, marshes and mangroves that support diversified fish species as well as increase the productivity. Since the present report on maiden occurrence of $S$. australasicus in the Bay of Bengal is based on a single specimen and no other individuals of this species have been recorded from the Bay of Bengal, it can be considered as a "casual" record. The highly discrete geographical distribution of species points towards a strong preference for particular type of habitat (Riipinen et al. 2017). As a non-indigenous fish species, $S$. australasicus could be problematic for the native fish fauna by competing for food, acting as a predator on native fish larvae and eggs, and occupying the native fish habitat.

In marine environments, marine traffic is globally the most significant vector in spreading non-indigenous species (Ruiz et al. 1997; Leppäkoski et al. 2002; Bax et al. 2003; Molnar et al. 2008). The Bay of Bengal is one of the busiest shipping routes and trade lines in the world. The dispersal and distribution patterns of many marine organisms are also driven by oceanographic conditions, which are influenced by global climate (Wilson et al. 2016). It is not possible to identify the actual native area from where $S$. australasicus introduced but it can be predicted that Southern coastal water of India might be the probable place. Because, in the Bay of Bengal, South-west coastal current flows northward in the south and southward in the north, forced by the equatorial 
winds during monsoon (Shetye et al. 1996) and Ocean current systems have been shown to play an important role in driving dispersal and population connectivity in many marine taxa.

\section{Conclusion}

This observation is the first documentation of S. australasicus in the coast of the Bay of Bengal, Bangladesh. A through study of the accessory catch of the coastal and marine water fisheries is emergent as it presents, nowadays, the only opportunity to access such sparse species.

\section{Compliance with Ethical Standard}

Conflict of interests: The authors declare that for this article they have no actual, potential or perceived conflict of interests.

Ethics committee approval: Not applicable

Financial disclosure: The authors did not receive any fund from any funding organization, institution, or agency.

Acknowledgement:Authors are highly grateful to the fisherman for catching the specimen as well as thankful to Dr. Tomas (Tom) Tomascik for providing key information about identification of the species.

\section{References}

Bax, N., Williamson, A., Aguero, M., Gonzalez, E., Geeves, W. (2003). Marine invasive alien species: a threat to global biodiversity. Marine Policy, 27, 313-323. https://doi.org/10.1016/S0308-597X(03)00041-1

Collette, B.B. (1995). Scombridae. Atunes, bacoretas, bonitos, caballas, estorninos, melva, etc. p. 1521-1543. In W. Fischer, F. Krupp, W. Schneider, C. Sommer, K.E. Carpenter and V. Niem (eds.) Guia FAO para Identification de Especies para lo Fines de la Pesca. Pacifico Centro-Oriental. 3 Vols. FAO, Rome.

Collette, B.B., Nauen, C.E. (1983). FAO Species Catalogue. Vol. 2. Scombrids of the world. An annotated and illustrated catalogue of tunas, mackerels, bonitos and related species known to date. Rome: FAO. FAO Fish. Synop. 125(2), 137 p.

Frimodt, C. (1995). Multilingual illustrated guide to the world's commercial warmwater fish. Fishing News Books, Osney Mead, Oxford, England. 215 p.
Gopakumar, G., Sarma, P.S.S., Thomas, K.T. (1993). First record of spotted chub mackerel Scomber australasicus $\mathrm{Cu}$ vier (scoivibridae: pisces) off Vizhinjam, southwest coast of India. Central Marine Fisheries Research Institute, Cochin682014 , India.

Hanif, M.A., Siddik, M.A.B., Chaklader, M.R., Nahar, A. Mahmud, S. (2015). Fish diversity in the southern coastal waters of Bangladesh: present status, threats and conservation perspectives. Croatian Journal of Fisheries, 73, 148-161. https://doi.org/10.14798/73.4.848

Hanif, M.A., Chaklader, M.R., Siddik, M.A.B., Nahar, A. Foysal, M.J., Kleindienst, R. (2019). Phenotypic variation of gizzard shad, Anodontostoma chacunda (Hamilton, 1822) based on truss network model. Regional Studies in Marine Science, 25, 100442.

https://doi.org/10.1016/j.rsma.2018.100442

Hanif, M.A., Islam, M.A., Siddik, M.A.B., Chaklader, M.R. (2018). Length-weight relationships of three estuarine fish species from Bangladesh. Journal of Applied Ichthyology, 34(4), 1065-1067.

https://doi.org/10.1111/jai.13707

Leppäkoski, E., Gollasch, S., Gruszka, P., Ojaveer, H., Olenin, S., Panov, V. (2002). The Baltic - a sea of invaders. Canadian Journal of Fisheries and Aquatic Sciences, 59, 1175-1188.

https://doi.org/10.1139/f02-089

May, J.L., Maxwell, J.G.H. (1986). Trawl fish from temperate waters of Australia. CSIRO Division of Fisheries Research, Tasmania. $492 \mathrm{p}$.

Molnar, J.L., Gamboa, R.L., Revenga, C., Spalding, M.D. (2008). Assessing the global threat of invasive species to marine biodiversity. Frontiers in Ecology and the Environment, $6,485-492$.

https://doi.org/10.1890/070064

Quader, O. (2010). Coastal and marine biodiversity of Bangladesh (Bay of Bengal). Proc. of International Conference on Environmental Aspects of Bangladesh (ICEAB10), Japan, Sept. 2010.

Riipinen, K., Mikkola, S., Ahola, M.K., Milla, M., Aalto, M.M., Olkinuora, A., Vesakoski, O. (2017). Habitat selection of the mud crab Rhithropanopeus harrisii in its newly invaded rang. Aquatic Invasions, 12(2), 191-200.

https://doi.org/10.3391/ai.2017.12.2.07 
Ruiz, G.M., Carlton, J.T., Grosholz, E.D., Hines, A.H. (1997). Global invasions of marine and estuarine habitats by non-indigenous species: mechanisms, extent, and consequences. American Zoologist, 37, 621-632.

https://doi.org/10.1093/icb/37.6.621

Siddik, M.A.B., Hanif, M.A., Nahar, A., Chaklader, M.R., Kleindienst, R. (2017). First record of the razorbelly scad Alepes kleinii (Bloch, 1793) (Carangidae) along the coast of Bangladesh. Marine Biodiversity Records, 10, 32.

https://doi.org/10.1186/s41200-017-0134-X

Stewart, J., Ferrell, D.J. (2001). Age, growth, and commercial landings of yellowtail scad (Trachurus novaezelandiae) and blue mackerel (Scomber australasicus) off the coast of New South Wales, Australia. New Zealand Journal of Marine and Freshwater Research, 35 (3), 541-551.

https://doi.org/10.1080/00288330.2001.9517021
Tzeng, C.H., Chen, C.S., Tang, P.C., Chiu, T.S. (2009). Microsatellite and mitochondrial haplotype differentiation in blue mackerel (Scomber australasicus) from the western North Pacific. ICES Journal of Marine Science, 66(5), 816825.

https://doi.org/10.1093/icesjms/fsp120

Wilson, L.J., Fulton, C.J., Hogg, A.M.C., Joyce, K.E., Radford, B.T.M., Fraser, C.I. (2016). Climate-driven changes to ocean circulation and their inferred impacts on marine dispersal patterns. Global Ecology and Biogeography, 25, 923-939.

https://doi.org/10.1111/geb.12456

Shetye, S.R., Gouveia, A.D., Shankar, D., Shenoi, S.S.C., Vinayachandran, P.N., Sundar, D., Michael, G.S., Nampoothiri, G. (1996). Hydrography and circulation in the western Bay of Bengal during the northeast monsoon. Journal of Geophysical Research, 101, 14,011 - 14,025.

https://doi.org/10.1029/95JC03307 